\title{
KURANGNYA MINAT BELAJAR PESERTA DIDIK YANG DISEBABKAN OLEH PENGGUNAAN GADGET
}

\author{
Tuti Citra Dewi \\ Program Studi Pendidikan Bimbingan Dan Konseling FIP UNP
}

Email: tuticitradewi3@gmail.com

\begin{abstract}
Abstrak
Gadget merupakan suatu alat teknologi yang saat ini berkembnag pesat dikalangan masyarakat terkhusus oleh para peserta didik, dimana berbagai fitur ditampilkan sehingga menarik perhatian peserta didik untuk menggunakannya. Namun tidak dipungkiri juga banyak disalahgunakan bagi pemakainya atau peserta didik sehingga berdampak buruk bagi nilai akademik dan prestasi peserta didik. Dengan selalu menggunakan gadget orang-orang yang berada disekitar pun ikut diabaikan, sehingga kurangnya interaksi peserta didik dalam melatih komunikasi antar sesama dan hubungan sosial yang sangat minim. Gadget banyak digunakan hanya untuk games, sosial media seperti instagram dan tidak digunakan untuk mencari informasi untuk pembelajarannya. Sehingga perlunya pengawasan orangtua dan bekerja sama dengan guru di sekolah.
\end{abstract}

Kata Kunci : Gadget, belajar dan interaksi

\section{A. Latar Belakang Masalah}

Media sosial memang dapat mendapatkan informasi begitu cepat tanpa harus membaca banyak artikel atau menonton berita sehingga anak lebih menggemari media masa karena kecepatan informasi yang diberikan. Namun media sosial ini memberikan efek yang berbagai macam pula, salah satunya efek buruk yang sudah disebutkan sebelumnya yaitu tersitanya waktu anak untuk belajar
(Muhammad Faja, Hadi Machmud, Imelda Wahyun, 2019).

Sejalan dengan hal tersebut untuk menyeimbangkan penggunaanmedia sosial pada dunia pendidikan dan proses pembelajaran kita tidak lepas dari sistem hukum yaitu, Menurut UU No. 20 Tahun 2003 tentang Sistem Pendidikan Nasional, pendidikan adalah usaha sadar dan terencana untuk mewujudkan suasana belajar dan proses pembelajaran agar peserta didik secara aktif mengembangkan 
potensi dirinya untuk memiliki kekuatan spiritual keagamaan, pengendalian dirinya, keperibadian, kecerdasan, akhlak mulia, serta keterampilan yang diperlukan dirinya, masyarakat bangsa dan negara. Modern technology has experienced vast expansion in recent years, leading to its extensive use by people from all generations. For a generation of young people, technology has assumed a substantial stake in their social and educational lives. The vast majority of adolescents have access to computers, the Internet, cell phones, video games, and many other forms of modern technology (Nakel \& Naval, 2017)

Kehadiran gadget pun menjadikan perubahan perilaku siswa, dimana ketika siswa sedang bergerombol atau berkerumun untuk sekedar membicarakan suatu hal, tidak jarang mereka akan lebih asik dengan gadgetnya daripada dengan orang yang ada didekatnya. Ketika sedang berjalan pun asik sambil memainkan gadgetnya. Siswa hanya menunduk menatap gadget tanpa menghiraukan lingkungan sekitar. Sehingga aksi tegur sapa, saling bercanda dengan teman menjadi berkurang. Dampak Negatif:

Gadget yang memiliki berbagai macam aplikasi akan membuat siswa lebih mementingkan diri sendiri. (2) Siswa yang telah menggunakan media sosial digadget mereka, lebih banyak menggunakan waktunya untuk berkomunikasi di media sosial dibandingkan belajar (Utomo \& Budi, 2015).

Bagi seorang siswa menggunakan gadget memiliki dampak positif maupun negatif. Dampak negatif yang cukup besar bagi siswa, adanya kemudahan dalam mengakses berbagai media infomasi dan teknologi, menyebabkan siswa menjadi malas bergerak dan beraktivitas, lebih memilih duduk diam di depan gadget dan menikmati dunia yang ada di dalamnya (Gin Gin Ginanjar, 2018).

Dampak yang sangat merugikan bila keberadaan penggunaan media sosial (facebook) dan gadget sebagai media informasi bagi siswa-siswi tidak diawasi dengan baik oleh orang tua. Kesalahan dalam pemahaman informasi yang diterima oleh siswasiswi dapat berakibat buruk, salah satunya pada motivasi belajar siswa di dunia pendidikan. Dalam hal ini, sangat dibutuhkan pengawasan dan kerjasama orang tua untuk mendampingi putra-putri mereka dalam mengakses penggunaan media sosial (facebook) dan gadget agar pengalahgunaan media tersebut menjadi tepat sasaran atau tepat guna bagi putra-putri (Mariskhana, 2018). 
Penggunaan gadget pada anak semakin meningkat. Berdasarkan penelitian yang dilakukan oleh Rideout diketahui bahwa terjadi peningkatan penggunaan media dan gadget pada anak yaitu 38\% pada tahun 2011 dan meningkat menjadi $72 \%$ pada tahun 2013. Salah satu faktor yang mendasari meningkatnya persentase anak yang menggunakan gadget yaitu karena semakin berkembangnya teknologi. Seiring berkembangnya teknologi, maka gadget tampil dengan sistem touch screen yang membuat siapapun lebih mudah untuk menggunakannya, terutama anak kecil yang belum bisa membaca sekalipun, seperti penggunaan smartphone (Anggraeni, 2019).

\section{B. Permasalahan}

The use of gadgets / mobile phones among children based on research results initiated by UNICEF and Ministry of Communications and Informatics of the Republic of Indonesia (2012) on 400 children and adolescent respondent saged 10-19 years, shows that 208 people (52\%) of respondents used mobile phones to not only communicate with their friends but also to access the internet (Miftahuddin \& Suyoto, 2018).
Dampak negatif dari gadget menurut (Maya Ferdiana Rozalia, 2017) adalah:

1. Penurunan konsentrasi saat belajar (pada saat belajar anak menjadi tidak fokus dan hanya teringat dengan gadget, misalnya anak teringat dengan permainan gadget seolah-olah dia seperti tokoh dalam game tersebut)

2. Malas menulis dan membaca, (hal ini diakibatkan dari penggunaan gadget misalnya pada saat anak membuka vidio di aplikasi Youtube anak cenderung melihat gambarnya saja tanpa harus menulis apa yang mereka cari)

3. Penurunan dalam kemampuan bersosialisasi, (misalnya anak kurang bermain dengan teman dilingkungan sekitarnya, tidak memperdulikan keadaan disekelilingnya.)

4. Kecanduan, (anak akan sulit dan akan ketergantungan dengan gadget karena sudah menajadi suatu hal yang menjadi kebutuhan untuknya)

5. Dapat menimbulkan gangguan kesehatan, (jelas dapat menimbulkan ganggunan kesehatan karena paparan radisasi yang ada pada gadget, dan juga dapat merusak kesehatan mata anak) 
6. Perkembangan kognitif anak usia dini terhambat, (kognitif atau pemikiran proses psikologis yang berkaitan bagaimana individu mempelajari, memperhatikan, mengamati, membayangkan, memperkirakan, menilai dan memikirkan lingkungannya akan terhambat)

7. Menghambat kemampuan berbahasa, (anak yang terbiasa menggunakan gadget akan cendrung diam, sering menirukan bahasa yang didengar, menutup diri dan enggan berkomunikasi dengan teman atau lingkungannya)

8. Dapat mempengaruhi perilaku anak usia dini, (seperti contoh anak bermain game yang memiliki unsur kekerasan yang akan mempengaruhi pola perilaku dan karakter yang dapat menimbulkan tindak kekerasan terhadap teman).

Beberapa penelitian menunjukan bahwa dampak penggunaan gadget Antara antara lain adalah terganggunya pertumbuhan otak anak, obesitas, kurang tidur, kelainan mental, sifat agresif serta radiasi emisi. Untuk itu perlu adanya batasan dalam menggunakan gadget pada anak. Perilaku penggunaan gadget dipengaruhi oleh berbagai faktor, salah satunya adalah pengetahuan.
Kurangnya pemahaman tentang dampak penggunaan gadget menjadikan anak- anak berperilaku menggunakan gadget secara berlebihan (Anggraeni, 2019).

Menurut (Maya Ferdiana Rozalia, 2017) Banyak ditemui siswa yang tidak mengerjakan tugas yang di berikan oleh guru, bahkan siswa terkadang merasa mengantuk ketika di kelas. Hal tersebut dialami oleh peneliti ketika guru kelas $\mathrm{V}$ menanyakan pekerjaan rumah, ada beberapa siswa yang tidak mengerjakan. Dan saat diberikan tugas, mereka tidak mau mengerjakan dengan alasan pusing. Hal tersebut serupa dengan sebuah kasus yang dari New York Times yaitu seorang anak yang mengalami kecanduan iPad. Anak tersebut terus meminta gadget nya ketika gadget tersebut tidak berada dalam genggaman tangannya. Anak tersebut dikatakan telah ketergantungan terhadap gadget. Anak tersebut tidak dapat terlepas dari gadget, bahkan saat makan, belajar, bermain, begitu pula saat tidur.

Waktu belajar siswa tersita dengan adanya gadget yang mereka miliki. Tidak hanya dirumah, disekolah siswa juga bermain gadget bersama temannya setelah pulang sekolah hingga lupa waktu dan sering pulang terlambat. Apabila kegiatan belajar 
siswa terganggu dengan terlalu banyak bermain gadget maka akan berakibat pada penurunan prestasi belajar siswa.

Seperti kasus pada siswa SDN Meruya Utara 04 petang Jakarta barat karena gadget membuat siswa menjadi malas belajar, namun ini merupakan kasus serius yang harus dipecahkan bisa dikatakan demikian dikarenakan karena semakin zaman, gadget pun semakin canggih jadi dapat mengakses kebutuhan yang diperlukan oleh siswa. Seperti buku online, game, dan lainlain. Demikian dapat menjadikan siswa menjadi malas atau tidak minat belajar (HESTIANA, 2019).

Sehingga Upaya guru dalam penanganan kecanduan Gadget dapat dimulai dari lingkungan keluarga, sekolah, dan masyarakat. Orang tua, guru, dan orang-orang di sekitar perlu bekerjasama untuk mengawasi dan menanggulangi kecanduan Gadget pada anak.

\section{Kajian Teoritis dan Pembahasan}

Menurut (Arifin, 2016) Fenomena penyimpangan sosial yang sering muncul dalam berita di berbagai media (baik cetak maupun elektronik) yang menimpa kalangan remaja di Indonesia (pada khususnya), memberikan gambaran kepada semua khalayak bahwa telah terjadi dekadensi moral. Munculnya video porno, aksi bullying dan kekerasan yang diperankan oleh kalangan ramaja usia sekolah (bahkan usia yang masih sangat belia yang seharusnya masih bermain) serta penyalahgunaan narkoba memberikan kesan kepada kita semua bahwa moralitas generasi bangsa sudah berada ujung tanduk (kalau tidak mau dikatakan diambang kehancuran).

Dalam menggunakan gadget, siswa seharusnya di damping oleh orang dewasa. Karena siswa terkadang salah dalam menggunakan teknologi tersebut. Selain itu orang tua berperan untuk membatasi penggunaan gadget. Karena radiasi gelombang elektromagnetik dari gadget dapat mengganggu penglihatan siswa. Serta orang tua melakukan seleksi terhadap aplikasi yang terdapat dalam gadget untuk mencegah adanya informasi yang negatif dari aplikasi tersebut.

Menurut (Sutrisno, 2018) Peran orangtua dan satuan pendidikan juga selalu membatasi penggunaan media digital dengan membuatkan jadwal atau buku harian media dan pendampingan terhadap generasi digital, hadirkan parental control, buat kesepakatan untuk acara televise yang boleh ditonton dan pastikan acara tersebut memang diperuntukan untuk anak-anak. 
Dorong anak untuk melakukan aktivitas lainnya dengan teman sebaya dan bersama orang tua, seperti bercocok tanam, bermain sepeda, main layang-layang, main bola, main gasing, petak umpet, main catur, berolahraga dan membaca buku. Jadilah role model (teladan) untuk anak anda. Jadikan kegiatan membaca sebagai aktivitas yang menyenangkan dan bermakna bagi anak, pupuklah gairah anak untuk membaca sejak dini karena membaca merupakan kunci pembuka jendela dunia.

Sehingga peran orangtua dan guru sangat diperlukan untuk mengarahkan anak-anak agar dapat mempergunakan teknologi secara bijak dan tepat sehingga anak mendapatkan manfaat yang positif. Hal-hal yang dapat dilakukan oleh orangtua dan guru adalah mengetahui konten yang diakses anak, membuat kesepakatan penggunaan internet, menggunakan internet untuk belajar, dan menggunakan software untuk menangkal situs berkonten negatif. Anak-anak harus diberitahu mengenai konten yang baik dan buruk dan diarahkan untuk melaporkan apabila menemukan konten-konten negatif. Dengan begitu, maka anak akan dapat memilih sendiri konten-konten yang baik .
Dengan pengawasan dari pihak sekolah akan membantu dalam sikap baik siswa dan tidak terpengaruh terlalu dalam dalam penggunaan gadget. Hal tersebut akan membuat mental siswa dalam nilai-nilai yang baik akan tertanam sejak dini. Siswa mencari informasi positif dalam mengakses internet dan tidak menimbulkan menurunnya daya piker dalam penelitian juga menjelaskan bimbingan revolusi mental lebih baik dikembangkan pada peserta didik.

Guided students and shaped to have a mental revolution values so that produce good students. The guidance of mental revolution which is done in intracurriculer activity which is implanted to the learners based on the values of Pancasila, the Constitution, UU No. 20 of 2003 and Pepres no 87 of 2017. Each character values formation should be attention the policies and applicable laws so that the attitudes and mental of the students do not conflict with the prevailing policies (Marsidin \& Ningrum, n.d.).

\section{Kesimpulan dan Saran}

Kemajuan teknologi yang sudah sangat canggih ini membuat seluruh kalangan masyarakat memanfaatkannya. Termasuk generasi abad 21 dimana bukan orang dewasa saja yang menggunakannya melainkan 
anak dibawah 5 tahun sudah bisa mengakses jejaring sosial dalam mencari informasi dan mengetahui dunia luar dalam sosial media.

Bagi peserta didik dengan teknologi seperti gadget memudahkan segalanya dalam mencari bahan pelajaran dan memudahkan dalam dunia pendidikan namun bagi peserta didik yang tidak pintar menggunakan gadget maka akan membawa dampak negative bagi penggunanya karena tidak semuanya positif dalam mengakses internet tersebut apalagi didukung games yang sangat menarik peserta didik untuk memainkanya.

Sehingga dengan hal tersebut dapat mengganggu proses pembelajaran seperti peserta didik yang tidak memeintingkan orang-orang sekitarnya lebih banyak interaksi di dunia luar dari pada dunia nyatanya. Hal tersebut juga dapat menurunnya tingkat prestasi peserta didik.

Dalam ini guru seharusnya bisa bekerja sama dengan orang tua peserta didk dalam pengelolaan penggunaan gadget dengan membatasinya. Orang tua dapat memantau situs apa saja yang dibukak oleh anak dan menjadikan anak sahabat sendiri. Orang tua lebih banyak berinteraksi dengan anak daripada gadget. Saat berada di dekat anak orang tua diharapkan tidak memegang gadget agar anak tidak terpengaruh oleh tingkah orang tua.

Di sekolah diharapkan guru dapat mengawasi saat belajar gadget masingmasing siswa di simpan dulu dan focus pada pembelajaran yang diberikan guru dan pembelajaran tersebut menarik dengan menggunakan kecanggihan teknologi.

Adanya kerja sama antara orangtua dan sekolah akan membawa kecerdasan apada siswa dalam menggunakan media sosial atau gadget dan membuat siswa tidak ketergantungan yang menimbulkan kesehatan pada mata dan malas untuk belajar serta interaksi dengan orang sekitar berkurang.

\section{DAFTAR PUSTAKA}

Anggraeni, S. (2019). Pengaruh Pengetahuan Tentang Dampak Gadget Bagi Kesehatan Terhadap Perilaku Penggunaan Gadget Pada Siswa SDN Kebun Bunga 6 Banjarmasin. Faletehan Health Journal, 6(2), 6468.

Arifin, Z. (2016). PERILAKU REMAJA PENGGUNA GADGET; Analisis Teori Sosiologi Pendidikan. Jurnal Pemikiran Keislaman, 26(2), 287316.

https://doi.org/10.33367/tribakti.v26i2 .219

Gin Gin Ginanjar, K. dan E. (2018). Penggunaan Gadget dalam Proses Pembelajaran Ilmu Pengetahuan 
Sosial Siswa Sekolah Dasar. PEDADIDAKTIKA: JURNAL ILMIAH PENDIDIKAN GURU SEKOLAH DASAR Penggunaan, 5(2), 372-379.

HESTIANA, V. (2019). Upaya guru dalam penanganan gadget pada siswa di sdn meruya utara 04 petang jakarta barat skripsi.

Mariskhana, K. (2018). Dampak Media Sosial ( Facebook ) dan Gadget Terhadap Motivasi Belajar. Perspektif, $X V I(1)$.

Marsidin, S., \& Ningrum, T. A. (n.d.). Student 's Mental Revolution Model At Senior High School. (2).

Maya Ferdiana Rozalia. (2017). POLA INTERAKSI SOSIAL SISWA PENGGUNA GADGET DI SMA N 1 SEMARANG. Jurnal Pemikiran Dan Pengembangan SD, 5(2), 722-731.

Miftahuddin, M. A., \& Suyoto, M. (2018). An Analysis of the Influence of Parenting Style on Childrenrs Involvement in the Decision of Purchasing Gadgets Purchasing Gadgets (A Case Study on Junior High School Students in Purwokerto City). Advances in Social Science, Education and Humanities Research, 231(Amca), 285-288. https://doi.org/10.2991/amca18.2018 .78

Muhammad Faja, Hadi Machmud, Imelda Wahyun, A. dan R. (2019). Penggunaan Media Sosial di Kalangan Pelajar (Studi Kasus di SD Negeri 2 Kendari). Diniyah: Jurnal Pendidikan Dasar, 53(9), 1689-1699. https://doi.org/10.1017/CBO97811074 15324.004

Nakel, M. P., \& Naval, S. (2017). Study of impact and dependency of electronic gadgets on health \& life style of students -A comparative study among youth population in MGM Campus , Aurangabad. International Journal of Science and Research (IJSR), 6(5), 2174-2178.

Sutrisno, F. \&. (2018). PENDAMPINGAN ORANG TUA DALAM MENGHADAPI ERA DIGITAL BAGI SISWA SEKOLAH DASAR SETIABUDI KECAMATAN KARET JAKARTA SELATAN. Jurnal Pemberdayaan Sekolah Dasar, 1(1), 19-22.

Utomo, C. B., \& Budi, T. (2015). Journal of Educational Social Studies PENGGUNA GADGET DI SMA N 1 SEMARANG. Journal of Educational Social Studies, 4(1), 1-5. 